\title{
Effect of the inactivation of lactate dehydrogenase, ethanol dehydrogenase, and phosphotransacetylase on 2,3-butanediol production in Klebsiella pneumoniae strain
}

\author{
Xuewu Guo, Chunhong Cao, Yazhou Wang, Chaoqun Li, Mingyue Wu, Yefu Chen, Cuiying Zhang, \\ Huadong Pei ${ }^{*}$ and Dongguang Xiao*
}

\begin{abstract}
Background: 2,3-Butanediol (2,3-BD) is a high-value chemical usually produced petrochemically but which can also be synthesized by some bacteria. To date, Klebsiella pneumoniae is the most powerful 2,3-BD producer which can utilize a wide range of substrates. However, many by-products are also produced by K. pneumoniae, such as ethanol, lactate, and acetate, which negatively regulate the 2,3-BD yield and increase the costs of downstream separation and purification.

Results: In this study, we constructed K. pneumoniae mutants with lactate dehydrogenase (LDH), acetaldehyde dehydrogenase (ADH), and phosphotransacetylase (PTA) deletion individually by suicide vector conjugation. These mutants showed different behavior of production formation. Knock out of IdhA had little influence on the yield of 2,3-BD, whereas knock out of adhE or pta significantly improved the formation of 2,3-BD. The accumulation of the intermediate of 2,3-BD biosynthesis, acetoin, was decreased in all the mutants. The mutants were then tested in five different carbon sources and increased 2,3-BD was observed. Also a double mutant strain with deletion of adhE and IdhA was constructed which resulted in accelerated fermentation and higher 2,3-BD production. In fed-batch culture this strain achieved more than $100 \mathrm{~g} / \mathrm{L}$ 2,3-BD from glucose with a relatively high yield of $0.49 \mathrm{~g} / \mathrm{g}$.

Conclusion: 2,3-BD production was dramatically improved with the inactivation of adhE and pta. The inactivation of IdhA could advance faster cell growth and shorter fermentation time. The double mutant strain with deletion of adhE and IdhA resulted in accelerated fermentation and higher 2,3-BD production. These results provide new insights for industrial production of 2,3-BD by K. pneumoniae.
\end{abstract}

Keywords: 2,3-butanediol, lactate dehydrogenase, ethanol dehydrogenase, phosphotransacetylase, Klebsiella pneumoniae

\section{Background}

Biorefineries for chemicals have attracted a great deal of interest because they can alleviate the dependence on oil supply for the production of platform chemicals, reduce environmental pollution, and ensure sustainable development [1,2]. Biological production of 2,3-butanediol (2,3$\mathrm{BD})$ has increased remarkably because of its wide industrial

\footnotetext{
*Correspondence: peihuadong@hotmail.com; xiao99@tust.edu.cn Key Laboratory of Industrial Fermentation Microbiology, Ministry of Education; Tianjin Industrial Microbiology Key Lab, College of Biotechnology, Tianjin University of Science and Technology, Box 08, No. 29, 13ST. TEDA, Tianjin 300457, China
}

(c) 2014 Guo et al.; licensee BioMed Central Ltd. This is an Open Access article distributed under the terms of the Creative Commons Attribution License (http://creativecommons.org/licenses/by/2.0), which permits unrestricted use, distribution, and reproduction in any medium, provided the original work is properly credited. The Creative Commons Public Domain Dedication waiver (http://creativecommons.org/publicdomain/zero/1.0/) applies to the data made available in this article unless otherwise stated. applications [3-5]. Many microorganisms classified in the genera Enterobacter, Klebsiella, Serratia, and Bacillus can produce 2,3-BD [3,4]. K. pneumoniae is a potentially useful producer in the industry because of its wide substrate spectrum, high efficiency, and cultural adaptability [6-8].

The fermentation pathways of mixed acid-2,3-BD in bacteria have been intensively studied [4]. Numerous studies have investigated the use of metabolic engineering to modify the metabolic pathways for improving 2,3BD production in Enterobacter aerogenes [9], Bacillus licheniformis [10], and K. oxytoca [11]. The formation of 
ethanol, lactate, and acetate competes with the biosynthesis of 2,3-BD for pyruvate, resulting in reduced 2,3$\mathrm{BD}$ production $[4,12-14]$. For example, the inactivation of acetaldehyde dehydrogenase gene significantly increases the 2,3-BD yield and decreases ethanol production [11]. Deletion of the $l d h$ gene encodes lactate dehydrogenase (LDH) in E. aerogenes, resulting in a very small amount of lactate yield and $16.7 \%$ more $2,3-\mathrm{BD}$ than that of the parent strain in batch fermentation [9]. The $l d h, l d h B$, and $l d h X$ genes in Lactococcus lactis, which encode $\mathrm{LDH}$, have been deleted, and the results showed that $\Delta l d h B$ is a valuable basis for engineering strategies for the production of reduced compounds [15]. The deletion of adhE in $K$. oxytoca increases the hydrogen yield of the mutant by $16.07 \%$ but decreases the ethanol concentration by $77.47 \%$, compared with those of the parent strain [16].

However, only a few studies have focused on K. pneumoniae engineering [17-19]. Ji et al. reported that the overexpression of NOX and nox-2, which can decrease the intracellular nicotinamide adenine dinucleotide plus hydrogen (NADH)/nicotinamide adenine dinucleotide $(\mathrm{NAD}){ }^{+}$ratio in $K$. pneumoniae, could improve acetoin production [17]. Zhang et al. investigated the effect of inactivating aldehyde dehydrogenase in $K$. pneumoniae on 1,3-propanediol production [18]. However, metabolic engineering focused on 2,3-BD production in K. pneumoniae has not yet been intensively investigated.

K. pneumoniae produces 2,3-BD from a wide range of substrates but generates numerous byproducts [20], thereby increasing the cost of product downstream separation [21]. The genetic alteration of $K$. pneumoniae perhaps makes it more efficiency in industry. In this study, $K$. pneumoniae mutants with deletion of $\mathrm{LDH}, \mathrm{ADH}$ and phosphotransacetylase (PTA) were constructed to evaluate the effect on 2,3-BD production. The metabolic flux and production of byproducts, such as ethanol, acetoin, lactic acid, and acetate, were also investigated.

\section{Results}

\section{$\mathrm{LDH}, \mathrm{ADH}$, and PTA activity assays}

The activities of LDH, ADH, and PTA in the mutants and parent strain were determined. As shown in Table 1, the LDH activities of $l d h A, a d h E$, and pta deletion strains were $12.02 \%, 93.35 \%$, and $97.80 \%$ of the parent strain, respectively. The PTA activities of $l d h A$, adhE, and pta deletion strains were $69.83 \%, 71.48 \%$, and $1.65 \%$ of the parent strain, respectively. The $\mathrm{ADH}$ activities of $l d h A$, $a d h E$, and pta deletion strains were $102.99 \%$, $2.24 \%$, and $85.76 \%$ of the parent strain, respectively. These results further confirmed the knockdown efficiency of these three genes respectively. Table 1 also shows that knockdown of one gene could affect the other enzyme expression or activity. For example, the $\Delta l d h A$ mutant showed high production of ethanol (Figure 1B), which may be caused by the high $\mathrm{ADH}$ activity. The production of lactate, ethanol and acetate was different in $l d h A, a d h E$, and pta deletion mutants, which also proved this point. Perhaps the different metabolic pathways are complicated, and could crosstalk with each other.

\section{Effect of IdhA, adhE, and pta deletion on cell growth}

To investigate the effect of $l d h A, a d h E$, and pta deletion on cell growth, the mutants and parent strain were cultured under the same conditions. In the first $8 \mathrm{~h}$, knockout of $l d h A$ promoted cell growth, whereas knockout of $a d h E$ and pta inhibited cell growth (Figure 2). The biomass accumulations of $\Delta l d h A$ and $\Delta p t a$ strains were higher than that of the parent strain at $12 \mathrm{~h}$. The $\Delta p t a$ strain achieved the highest biomass compared with other mutants and parent strains at $12 \mathrm{~h}$, indicating that the strain exhibited good fermentation performance, although the growth rate was lower in the first $8 \mathrm{~h}$.

\section{Internal redox state of IdhA, adhE, and pta deletion strains}

The internal redox state was investigated from $4 \mathrm{~h}$ to $36 \mathrm{~h}$ in the fed-batch fermentation. As shown in Figure 3, in $\Delta l d h A$ mutant fermentations, the total dinucleotide pool and $\mathrm{NADH} / \mathrm{NAD}^{+}$ratio was very high in the early exponential period, then gradually decreased in the late stationary phase, whereas, the total dinucleotide pool and $\mathrm{NADH} / \mathrm{NAD}^{+}$ratio in $a d h E$ and pta mutants was low at $4 \mathrm{~h}$ to $12 \mathrm{~h}$, then increased significantly from 18 h, respectively. Compared with $K$. pneumoniae parent strain (KG1), the $\mathrm{NAD}^{+}$level decreased whereas NADH increased in the fermentation of $\triangle a d h E$ and $\triangle p t a \mathrm{mu}-$ tants. Thus, the NADH/NAD ${ }^{+}$ratio was much higher in

Table 1 Lactate dehydrogenase (LDH), phosphotransacetylase (PTA) and acetaldehyde dehydrogenase (ADH) activity of $K$. pneumoniae parent strain (KG1) and its mutants, the values represent mean \pm SD

\begin{tabular}{|c|c|c|c|c|c|c|}
\hline \multirow{2}{*}{ Strains } & \multicolumn{2}{|c|}{ LDH activity } & \multicolumn{2}{|c|}{ PTA activity } & \multicolumn{2}{|c|}{ ADH activity } \\
\hline & U/mg protein & Percentage of wild type & $\mathrm{U} / \mathrm{mg}$ protein & Percentage of wild type & $\mathrm{U} / \mathrm{mg}$ protein & Percentage of wild type \\
\hline KG1 & $4.66 \pm 0.23$ & 100 & $2.42 \pm 0.04$ & 100 & $2.67 \pm 0.22$ & 100 \\
\hline$\Delta / d h A$ & $0.56 \pm 0.03$ & 12.02 & $1.69 \pm 0.05$ & 69.83 & $2.75 \pm 0.21$ & 102.99 \\
\hline$\Delta a d h E$ & $4.35 \pm 0.31$ & 93.35 & $1.73 \pm 0.03$ & 71.48 & $0.06 \pm 0.01$ & 2.24 \\
\hline$\Delta p t a$ & $4.56 \pm 0.25$ & 97.80 & $0.04 \pm 0.01$ & 1. 65 & $2.29 \pm 0.15$ & 85.76 \\
\hline
\end{tabular}



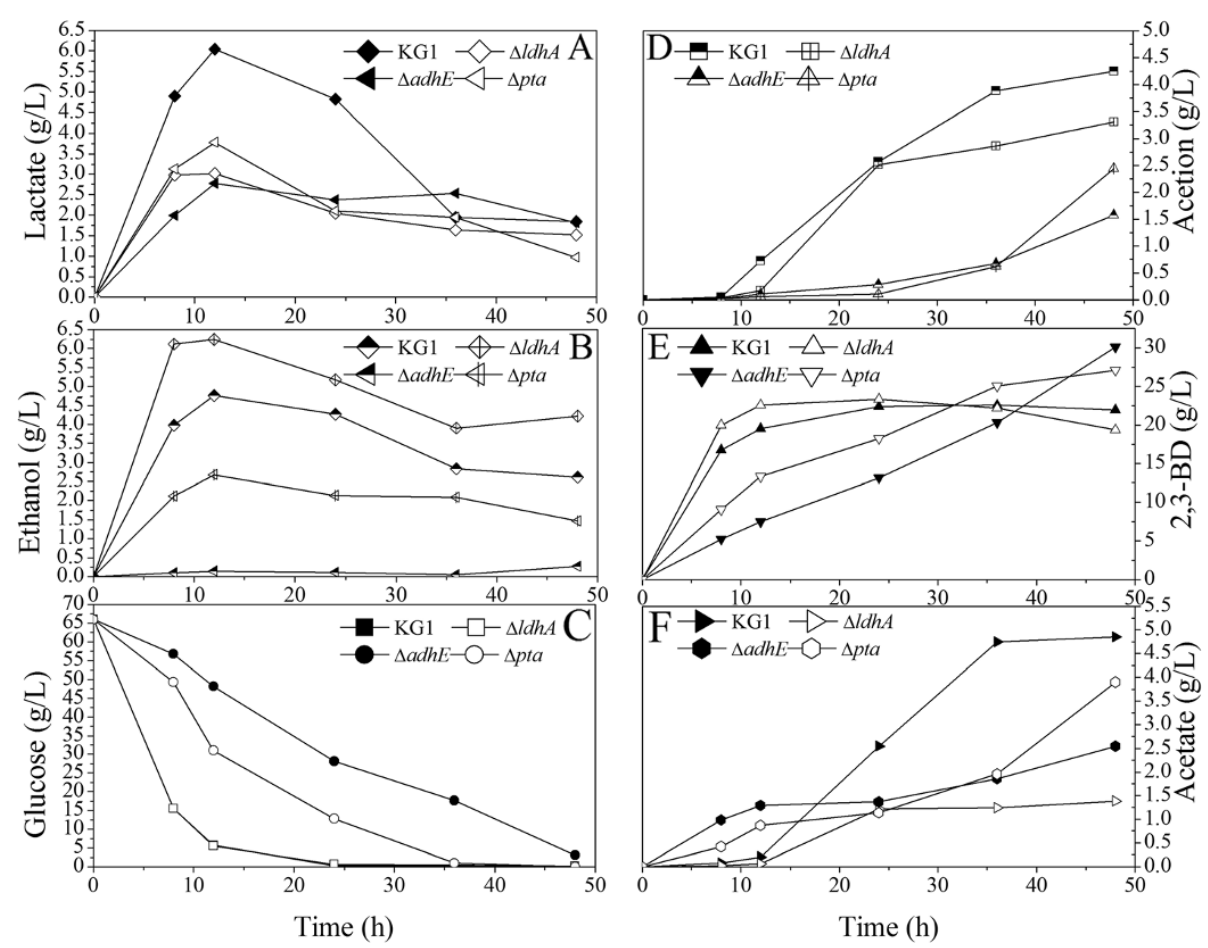

Figure 1 Metabolite profiles of the $K$. pneumoniae parent strain (KG1) and the mutants in the batch culture. KG1: the parent strain; $\Delta / d h A, \Delta a d h E$, and $\Delta p t a$ : the mutants. A) Lactate; B) Ethanol; C) Glucose; D) Acetion; E) 2,3-BD; F) Acetate. The curves were calculated from one measurement of three experiments.

the $\triangle a d h E$ and $\Delta p t a$ from $12 \mathrm{~h}$. This variation coincides with 2,3-BD flux distribution.

\section{Metabolic profiles of the mutants and their effect on 2,3-BD production}

The concentrations of major metabolites in mutants and parent strains were investigated (Figure 1). As shown in

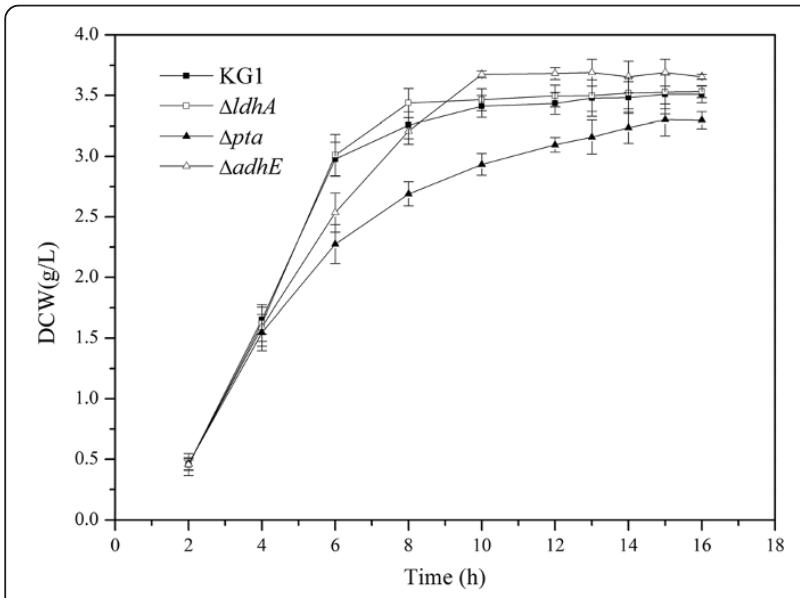

Figure 2 Growth curves of the parent and mutants of $K$. pneumoniae with $20 \mathrm{~g} / \mathrm{L}$ glucose. KG1: the parent strain; $\Delta / d h A$, $\Delta a d h E$, and $\Delta p t a$ : the mutants. DCW, dry cell weight. The curves were calculated from one measurement of three experiments.
Figure 1, three mutants showed different metabolic performance. The inactivation of $l d h A$ resulted in $90 \%$ reduction in lactate production, which confirmed that $l d h A$ was the major LDH manufacturing gene in $K$. pneumoniae. The 2,3-BD production of $\Delta l d h A$ reached $22.52 \mathrm{~g} / \mathrm{L}$ at $12 \mathrm{~h}$, whereas that of the parent strain was only $19.51 \mathrm{~g} / \mathrm{L}$. The maximum 2,3-BD production of $\Delta l d h A$ was $23.32 \mathrm{~g} / \mathrm{L}$ at $24 \mathrm{~h}$, whereas that of the parent strain reached maximum $(22.57 \mathrm{~g} / \mathrm{L})$ at $36 \mathrm{~h}$. The fermentation time was shortened from $36 \mathrm{~h}$ to $24 \mathrm{~h}$. For byproducts, the $\Delta l d h A$ mutant strain produced $18.87 \mathrm{~g} / \mathrm{L}$ succinate and $12.31 \mathrm{~g} / \mathrm{L}$ ethanol, which were $67.4 \%$ and $53.7 \%$ higher than those in the wild-type strain. However, 2,3-BD production did not increase significantly.

The highest production of 2,3-BD was achieved at $48 \mathrm{~h}$ by the $\triangle a d h E$ strain, which reached $30.10 \mathrm{~g} / \mathrm{L}$. And the highest production of 2,3-BD by the parent strain was $22.57 \mathrm{~g} / \mathrm{L}$ in $36 \mathrm{~h}$. Although the fermentation time was longer than the wild-type strain, 2,3-BD production increased by $33.65 \%$, and yields of approximately $94 \%$ were obtained. The recombinant strains produced less acetoin, acetic acid, ethanol, and lactic acid, because the corresponding enzyme activity was lower..

The 2,3-BD production also reached $27.32 \mathrm{~g} / \mathrm{L}$ at $48 \mathrm{~h}$ in the $\Delta p t a$ strain. Lactate production was lower than the $\triangle a d h E$ and parent strains. The $\Delta p t a$ strain produced more acetate, acetoin, and ethanol than the $\triangle a d h E$ 

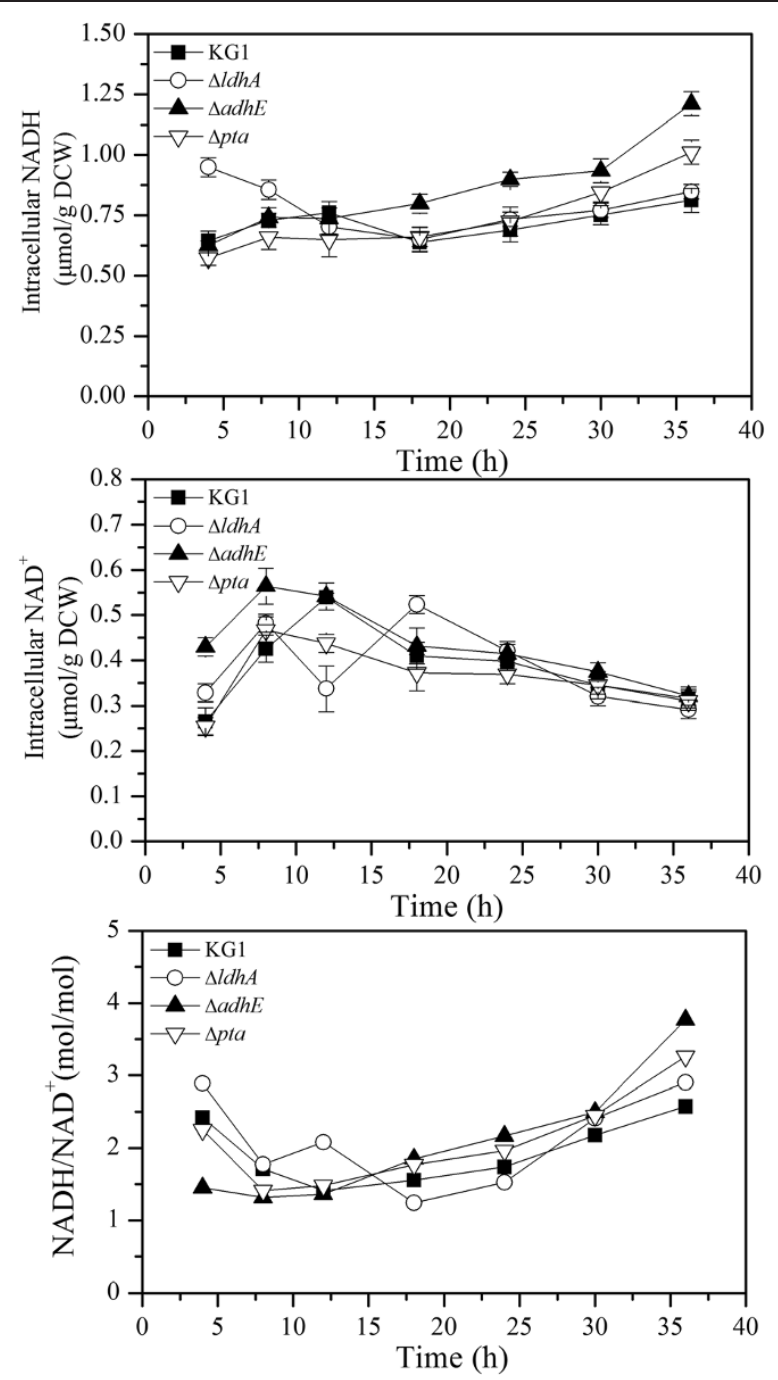

Figure 3 Time courses profile of nucleotide pools in $K$. pneumoniae parent strain (KG1) and the mutants in the batch culture. KG1: the parent strain; $\Delta / d h A, \triangle a d h E$, and $\Delta p t a$ : the mutants. The curves were calculated from one measurement of three experiments. NAD, nicotinamide adenine dinucleotide; NADH, nicotinamide adenine dinucleotide plus hydrogen; DCW, dry cell weight.

strain, but their production rates were lower than those of the wild-type strain. Acetate production decreased by only $19.58 \%$ compared to that of the parent strain.

\section{Carbon source effects on the $\Delta / d h A, \Delta a d h E$, and $\Delta p t a$ mutants}

K. pneumoniae can naturally use a wide spectrum of carbon sources effectively [5]. Five carbon sources, such as glucose, galactose, fructose, maltose, and lactose, were chosen to test the metabolic effects of mutants (Tables 2 and 3). As shown in Table 2, ethanol production and glucose consumption significantly increased, whereas lactate and acetate production decreased by the $\Delta l d h A$ strain in a flask culture with glucose, galactose, fructose, or maltose, respectively. However, 2,3-BD production slightly increased. This result suggests that the reduced
$\mathrm{pH}$ in the $\operatorname{ldh} A$ mutant cultivation media increases 2,3$\mathrm{BD}$ production [22]. Lactate and acetate production decreased, which alleviated the inhibition of cell growth. The $\Delta l d h A$ mutant underwent less $\mathrm{pH}$ shock than that of the wild-type strain; thus, a shorter fermentation time was observed.

The 2,3-BD production of the $\Delta a d h E$ and $\Delta p t a \mathrm{mu}-$ tants increased similarly with galactose, fructose, and maltose (Table 3). These carbon sources are consumed in the glycolytic pathway, similar to glucose. The highest production of 2,3-BD was observed in $\triangle a d h E$, but the $\Delta p t a$ strain exhibited high acetoin production.

The wild-type KG1 was ineffective in converting lactose to 2,3-BD because of its low lactose consumption rate. Galactose consumption slightly increased in the 
Table 2 Comparison of $K$. pneumoniae parent strain (KG1) and the $\Delta / d h A$ using several carbon sources in a 12-h flask cultivation, the values represent mean \pm SD

\begin{tabular}{|c|c|c|c|c|c|c|c|c|c|c|c|c|}
\hline rain & $\begin{array}{l}\text { Carbon } \\
\text { source } \\
(50 \mathrm{~g} / \mathrm{L})\end{array}$ & $\begin{array}{c}\text { Consumed } \\
\text { carbon } \\
\text { source }(\mathrm{g} / \mathrm{L})\end{array}$ & $\begin{array}{c}2,3- \\
\text { Butanediol } \\
\text { (g/L) }\end{array}$ & $\begin{array}{l}\text { L-Lactate } \\
\text { (g/L) }\end{array}$ & $\begin{array}{c}\text { D-Lactate } \\
\text { (g/L) }\end{array}$ & $\begin{array}{c}\text { Acetate } \\
\text { (g/L) }\end{array}$ & $\begin{array}{c}\text { Acetoin } \\
(\mathrm{g} / \mathrm{L})\end{array}$ & $\begin{array}{l}\text { thanol } \\
(g / L)\end{array}$ & $\begin{array}{c}\text { Biomass } \\
(\mathrm{g} / \mathrm{L})\end{array}$ & $\begin{array}{c}2,3- \\
\text { Butanediol } \\
\text { yield }(g / g)\end{array}$ & $\mathbf{R}_{\mathrm{H}}$ & $\mathbf{R}_{\mathrm{C}}$ \\
\hline & Glucose & $44.41 \pm 0.45$ & \pm 0.05 & & & 4 & .02 & 21 & 14 & 0.31 & 0.82 & 0.98 \\
\hline & Lactose & $24.04 \pm 0.23$ & $5.16 \pm 0.03$ & $2.05 \pm 0.02$ & 3 & 0 & 3 & & & 0.21 & 56 & 1.57 \\
\hline \multirow[t]{5}{*}{ KG1 } & Fructose & $38.11 \pm 0.32$ & $13.26 \pm 0.11$ & $2.64 \pm 0.04$ & $1.53 \pm 0.06$ & $0.81 \pm 0.06$ & $0.54 \pm 0.06$ & $3.68 \pm 0.12$ & $4.02 \pm 0.07$ & 0.35 & 0.97 & 1.1 \\
\hline & Galactose & $31.52 \pm 0.28$ & 8 & 2 & 8 & 7 & .04 & 11 & $3.49 \pm 0.11$ & 0.33 & 01 & 1.28 \\
\hline & altose & 41.63 & 5.05 & $3.19 \pm 0.03$ & $.58 \pm 0.21$ & $.38 \pm 0.02$ & - & 4.5 & $3.54 \pm$ & 0. & 1.24 & 1.3 \\
\hline & Glucose & $4+1.14$ & 10.0 & 2. & 1 & 4 & 0 & 32 & 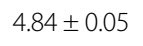 & 0.35 & 4 & 1.13 \\
\hline & Lactose & $18.24 \pm 0.15$ & $97 \pm 0.05$ & $1.66 \pm 0.02$ & $0.44 \pm 0.05$ & $.16 \pm 0.04$ & $0.19 \pm 0.03$ & $1.29 \pm 0.16$ & $1.57 \pm 0.03$ & 0.16 & 0.54 & 1.3 \\
\hline \multirow[t]{3}{*}{$\Delta / d h A$} & Fructose & 49.52 & .24 & 3.04 & 6 & 5 & 0.67 & 4.92 & 4 & 0. & 1.11 & 0 \\
\hline & Galactose & $47.04 \pm 0.28$ & $14.33 \pm 0.15$ & $2.82 \pm 0.02$ & $0.12 \pm 0.02$ & $0.81 \pm 0.03$ & $2.11 \pm 0.11$ & $5.55 \pm 0.22$ & $4.49 \pm 0.04$ & 0.30 & 1.13 & 1.0 \\
\hline & Maltose & $49.59 \pm 0.35$ & $18.75 \pm 0.11$ & $3.95 \pm 0.07$ & $0.08 \pm 0.02$ & $.27 \pm 0.05$ & $1.37 \pm 0.05$ & $6.01 \pm 0.24$ & $5.06 \pm 0.15$ & 0.38 & 1.18 & 1.2 \\
\hline
\end{tabular}

mutants, but the reason remains unclear. The 2,3-BD production from lactose decreased in mutants. However, the consumption and 2,3-BD production from galactose in mutants were better than those in the parent strain KG1. Overall, the mutants enhanced 2,3-BD production with glucose, galactose, fructose, or maltose, respectively, but 2,3-BD production decreased with the use of lactose.

Metabolic profiles of $\triangle a d h E \Delta / d h A$ strain and production of 2,3-BD by fed-batch culture

As shown in Figure 1 and Figure 2, the $\operatorname{ldh} A$ deletion could promote cell growth, and adhE deletion could increase 2,3-BD yield, so a double-mutant $\triangle a d h E \Delta l d h A$ was constructed to produce 2,3-BD with high efficiency. As shown in Figure 4, the 2,3-BD production was achieved at $24 \mathrm{~h}$ by the double-knockout mutant, and reached $29.48 \mathrm{~g} / \mathrm{L}$. The productions of lactate and ethanol decreased significantly and the rate of glucose consumption increased, compared with the parent strain, respectively.

Fed-batch culture could enhance 2,3-BD production and reduce the cost of production by taking full advantage of the substrate. Thus, fed-batch fermentations were conducted in a 5-L bioreactor. As shown in Figure 5, a fed-batch culture was carried out by

Table 3 Comparison of $K$. pneumoniae parent strain (KG1), $\Delta a d h E$ and the $\Delta p t a$ using several carbon sources in a $36-h$ flask cultivation, the values represent mean \pm SD

\begin{tabular}{|c|c|c|c|c|c|c|c|c|c|}
\hline Strain & $\begin{array}{l}\text { Carbon source } \\
(50 \mathrm{~g} / \mathrm{L})\end{array}$ & $\begin{array}{l}\text { Consumed carbon } \\
\text { source }(g / L)\end{array}$ & $\begin{array}{c}\text { 2,3-Butanediol } \\
(\mathrm{g} / \mathrm{L})\end{array}$ & $\begin{array}{l}\text { Lactate } \\
(\mathrm{g} / \mathrm{L})\end{array}$ & $\begin{array}{l}\text { Acetate } \\
(\mathrm{g} / \mathrm{L})\end{array}$ & $\begin{array}{l}\text { Acetoin } \\
(\mathrm{g} / \mathrm{L})\end{array}$ & $\begin{array}{c}\text { Ethanol } \\
(\mathrm{g} / \mathrm{L})\end{array}$ & $\begin{array}{c}\text { Biomass } \\
(\mathrm{g} / \mathrm{L})\end{array}$ & $\begin{array}{l}\text { 2,3-Butanediol } \\
\text { yield }(\mathrm{g} / \mathrm{g})\end{array}$ \\
\hline \multirow{5}{*}{ KG1 } & Glucose & $49.29 \pm 0.65$ & $16.76 \pm 0.22$ & $3.62 \pm 0.21$ & $4.52 \pm 0.45$ & $1.73 \pm 0.09$ & $2.67 \pm 0.16$ & $4.80 \pm 0.32$ & 0.34 \\
\hline & Lactose & $49.39 \pm 0.59$ & $16.28 \pm 0.13$ & $2.95 \pm 0.15$ & $2.98 \pm 0.28$ & $3.26 \pm 0.11$ & $4.16 \pm 0.32$ & $2.80 \pm 0.43$ & 0.33 \\
\hline & Fructose & $44.84 \pm 0.61$ & $14.41 \pm 0.16$ & $2.27 \pm 0.12$ & $2.85 \pm 0.33$ & $2.46 \pm 0.13$ & $3.22 \pm 0.25$ & $4.06 \pm 0.52$ & 0.32 \\
\hline & Galactose & $34.89 \pm 0.48$ & $10.27 \pm 0.11$ & $3.33 \pm 0.15$ & $2.83 \pm 0.32$ & $1.80 \pm 0.10$ & $2.64 \pm 0.28$ & $3.89 \pm 0.18$ & 0.29 \\
\hline & Maltose & $49.20 \pm 0.51$ & $17.30 \pm 0.21$ & $2.03 \pm 0.14$ & $2.79 \pm 0.16$ & $3.56 \pm 0.12$ & $4.45 \pm 0.45$ & $3.87 \pm 0.21$ & 0.35 \\
\hline \multirow{5}{*}{$\Delta a d h E$} & Glucose & $49.27 \pm 0.42$ & $23.65 \pm 0.25$ & $1.35 \pm 0.09$ & $2.05 \pm 0.12$ & $0.60 \pm 0.04$ & $0.52 \pm 0.04$ & $3.95 \pm 0.52$ & 0.48 \\
\hline & Lactose & $17.76 \pm 0.25$ & $8.76 \pm 0.12$ & $1.61 \pm 0.11$ & $3.85 \pm 0.42$ & $2.01 \pm 0.08$ & $0.36 \pm 0.06$ & $1.76 \pm 0.35$ & 0.49 \\
\hline & Fructose & $49.47 \pm 0.52$ & $21.40 \pm 0.24$ & $1.48 \pm 0.13$ & $1.58 \pm 0.12$ & $0.83 \pm 0.06$ & $0.94 \pm 0.02$ & $3.25 \pm 0.28$ & 0.43 \\
\hline & Galactose & $36.35 \pm 0.42$ & $14.05 \pm 0.42$ & $0.73 \pm 0.07$ & $1.96 \pm 0.09$ & $3.70 \pm 0.21$ & $0.65 \pm 0.03$ & $2.99 \pm 0.42$ & 0.39 \\
\hline & Maltose & $49.49 \pm 0.47$ & $18.18 \pm 0.23$ & $2.96 \pm 0.10$ & $1.27 \pm 0.08$ & $4.58 \pm 0.24$ & $0.91 \pm 0.08$ & $4.27 \pm 0.25$ & 0.36 \\
\hline \multirow{5}{*}{$\Delta p t a$} & Glucose & $49.27 \pm 0.54$ & $20.20 \pm 0.62$ & $0.77 \pm 0.09$ & $3.15 \pm 0.11$ & $2.31 \pm 0.15$ & $1.69 \pm 0.32$ & $3.40 \pm 0.52$ & 0.41 \\
\hline & Lactose & $10.10 \pm 0.25$ & $2.98 \pm 0.11$ & $0.96 \pm 0.07$ & $2.01 \pm 0.10$ & - & $0.30 \pm 0.02$ & $1.01 \pm 0.46$ & 0.30 \\
\hline & Fructose & $49.51 \pm 0.55$ & $18.36 \pm 0.32$ & $1.01 \pm 0.10$ & $2.20 \pm 0.09$ & $2.81 \pm 0.11$ & $1.87 \pm 0.14$ & $2.96 \pm 0.26$ & 0.37 \\
\hline & Galactose & $39.49 \pm 0.23$ & $11.88 \pm 0.12$ & $0.19 \pm 0.06$ & $1.98 \pm 0.12$ & $1.56 \pm 0.14$ & $1.29 \pm 0.21$ & $3.27 \pm 0.43$ & 0.30 \\
\hline & Maltose & $40.28 \pm 0.54$ & $14.57 \pm 0.24$ & $4.68 \pm 0.08$ & $2.50 \pm 0.14$ & $1.91 \pm 0.12$ & $3.26 \pm 0.33$ & $3.74 \pm 0.44$ & 0.36 \\
\hline
\end{tabular}




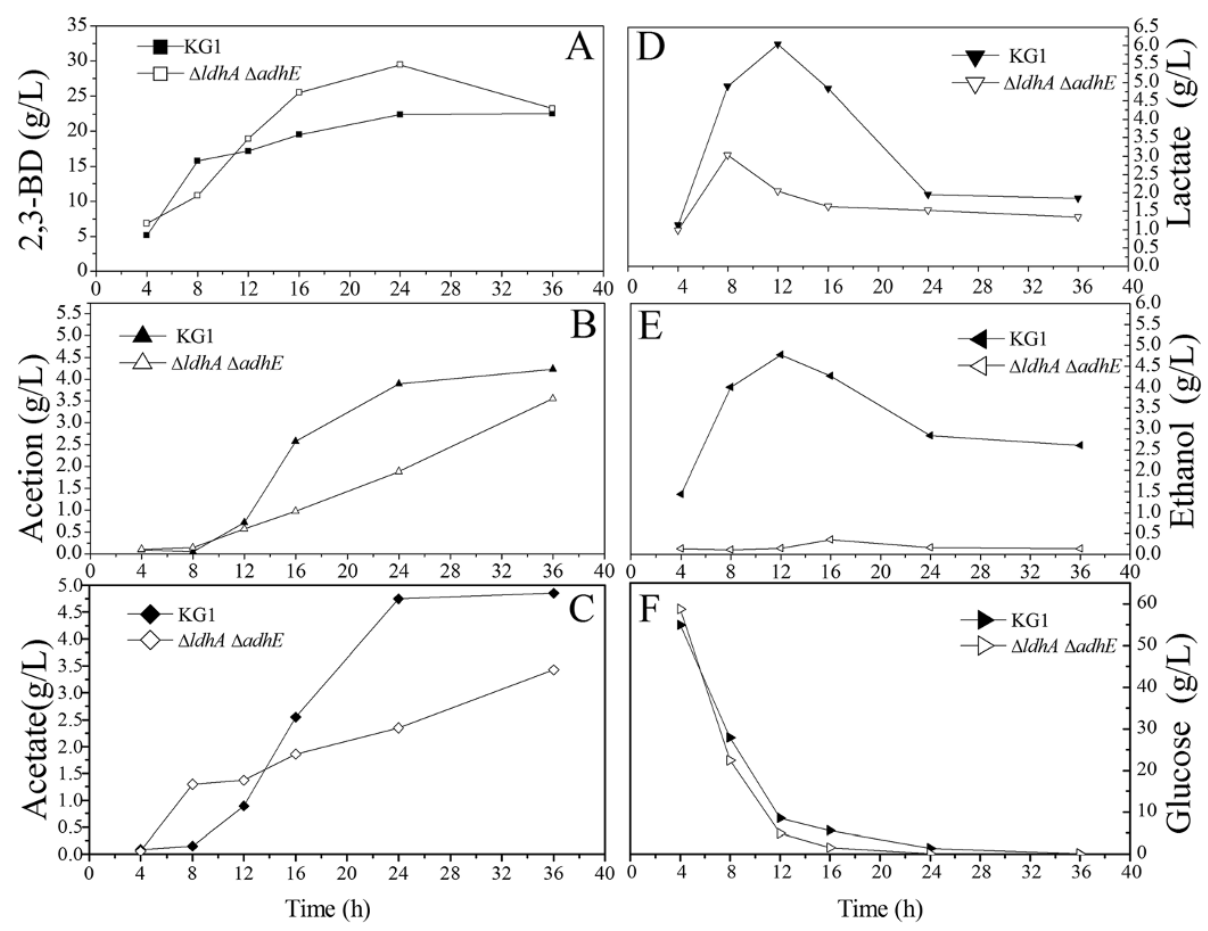

Figure 4 Metabolite profiles of the $K$. pneumoniae parent strain (KG1) and $\Delta / d h A \Delta a d h E$ mutant in the batch culture. The curves were calculated from one measurement of three experiments. 2,3-BD, 2,3-Butanediol. A) 2,3-BD; B) Acetion; C) Acetate; D) Lactate; E) Ethanol; F) Glucose.

feeding glucose solution. In order to maintain optimum levels of glucose, about $750 \mathrm{~mL}$ of $600 \mathrm{~g} / \mathrm{L}$ glucose was added to the bioreactor throughout the fermentation. After $52 \mathrm{~h}$, the fed-batch fermentation of the $\triangle a d h E \Delta l d h A$ strain produced about $116 \mathrm{~g} / \mathrm{L}$ of 2,3-BD, whereas the time courses of the other metabolites had the same tendency with the batch culture (Figure 5).

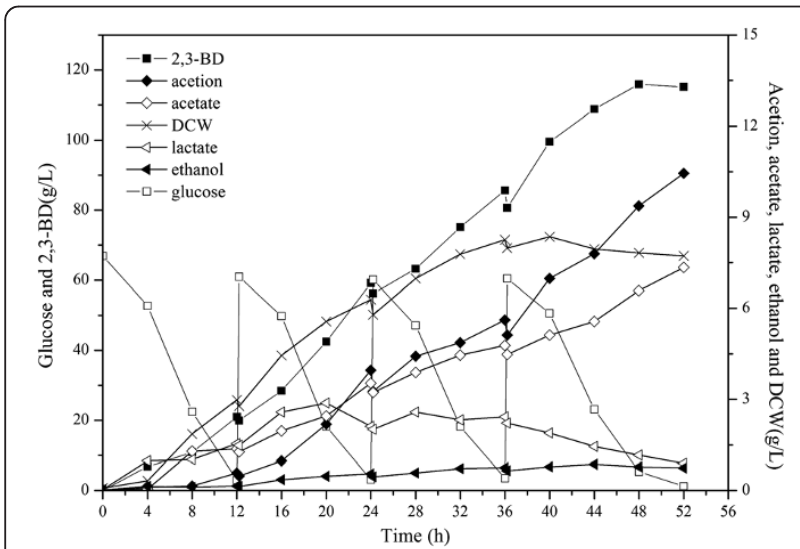

Figure 5 Fed-batch fermentation profiles of $\Delta / d h A \Delta a d h E$ mutant. DCW, dry cell weight; 2,3-BD, 2,3-Butanediol. The curves were calculated from one measurement of three experiments.

\section{Discussion}

Numerous attempts have been made to reduce the carbon flux to by-products and increase the NADH availability for 2,3-BD through metabolic engineering in several strains [23-25]. In this study, to channel the reducing power toward the desired redox-reaction, genes encoding LDH, ADH, and PTA (ldhA, adhE, and pta) of K. pneumoniae were knocked out. First, lactate, ethanol, and acetate are the major byproducts that consume carbon flux from carbon in 2,3-BD production. Second, the formation of lactate and ethanol requires NADH, which competes with 2,3-BD production process.

Genetically engineered strains always exhibit a slow growth speed because of the changes in the metabolic pathway $[17,26]$. However, in our system, the mutants showed different cell growth patterns (Figure 2). The $\Delta l d h A$ strain showed faster growth than the $\Delta p t a, \Delta a d h E$, and parent strains. The main reason for the increase in cell growth may be due to the decrease in lactate production, resulting in a low acidification rate of the media. Indeed, compared to the wild-type strain, $\mathrm{NaOH}$ spent by the $l d h A$ mutant in batch fermentation decreased by $70 \%$. Deletion of the $l d h A$ maybe increased the carbon flux to acetyl-CoA, which was subsequently converted to ethanol and biomass. However, 2,3-BD production did not improve significantly, which is consistent with a previous study [27]. The increased 
production of ethanol was attributed to the redirection of carbon flux and NADH to ethanol production.

In anaerobic conditions, cells are forced to produce different byproducts (mostly ethanol) for the balancing of $\mathrm{NADH}_{2}$ and the 2,3-BD yield is always limited. However, in our system, ethanol amounts were low (as shown in Table 2 and Table 3). We have repeated this experiment more than 10 times, and obtained the same result every time. The $\mathrm{NADH}$ regeneration was mainly caused by the ethanol, acetoin and succinic acid pathway [28]. But under microaerobic conditions, the other pathway was perhaps also involved, such as: $\mathrm{NADH}_{2}+\mathrm{ADP}+1 / 2 \mathrm{O}_{2} \rightarrow \mathrm{NAD}^{+}+\mathrm{ATP}+$ $\mathrm{H}_{2} \mathrm{O}$ [29]. On the other hand, Ji et al. also reported that the 2,3-BD yield of the mutant with inactivation of acetaldehyde dehydrogenase gene increased by $6.67 \%$, whereas ethanol and acetoin concentration was $0.45 \mathrm{~g} / \mathrm{L}$ and $0.98 \mathrm{~g} / \mathrm{L}$, decreased by $92.21 \%$ and $64.1 \%$, respectively [11]. The values of reducing equivalent recovery $\left(\mathrm{R}_{\mathrm{H}}\right)$ (Table 2) were scattered between 0.54 and 1.24, which also suggests that there are existed other NADH regeneration pathway.

The $\Delta p t a$ and $\Delta a d h E$ strains showed slower cell growth than the wild-type strain in the first $8 \mathrm{~h}$, whereas the $\triangle a d h E$ strain achieved the highest biomass accumulation. The inactivation of ADH and PTA genes significantly increased 2,3-BD production. The production of acetate and ethanol dramatically decreased in both mutant strains, which redirected the carbon flux to 2,3-BD production, and the increased intracellular NADH concentration and the $\mathrm{NADH} / \mathrm{NAD}^{+}$ratio altered the metabolite spectrum of the mixed acid-2,3-BD fermentation pathway. The most direct result was the reduction in acetoin accumulation with increasing 2,3-BD production. However, the highest production of 2,3-BD was obtained by the $\triangle a d h E$ strain compared to the mutants and wild-type strains. This result may be due to the reduction in acetoin and ethanol production in $\triangle a d h E$, which decreased by $62.73 \%$ and $89.65 \%$, respectively, compared with those in the parent strain.

The effect of $\mathrm{LDH}, \mathrm{ADH}$, and PTA disruption was tested using five different carbon sources. The $l d h A$ mutant showed an improvement in carbon source consumption rates, biomass production, and 2,3-BD production with all carbon sources, except for lactose, compared to the control cells. As shown in Table 2 and Table 3, the yield of ethanol was very high when maltose was used as the substrate in both mutants and wild-type strains, and 2,3-BD production was not the highest, because the ethanol formation pathway competed with 2,3-BD production pathway for the $\mathrm{NADH}$ and carbon flux supply. We also found that, when galactose was used as the carbon source in a 36-h flask cultivation, the lactate content was much lower in the mutants than in the wild-type strains. This is also interesting; perhaps knockout of these genes partially blocks the lactate metabolic pathway, providing more energy and sources for the strains to produce 2,3-BD. The 2,3-BD production increased significantly in the pta and $a d h E$ mutants from all carbon sources, except lactose. However, their biomass production and carbon source consumption rates decreased compared with those of the parent strain.

The carbon source consumption, biomass production, and 2,3-BD production rates decreased significantly in the mutants when lactose was used as the major carbon source. Lactose consumed only $10.1 \mathrm{~g}$ and $17.78 \mathrm{~g}$ in $\Delta p t a$ and $\triangle a d h E$ strains for $36 \mathrm{~h}$, respectively, which was $20.44 \%$ and $35.39 \%$ of that of the parent strain. Thus, the production of byproducts significantly decreased. In K. pneumoniae strains, lactose hydrolysis is the limiting step because lactose must first be hydrolyzed by enzymatic processes into monosaccharides, which can then be further converted into butanediol in a second stage when lactose is used as a major carbon source [30]. The deletion of $l d h A$, $a d h E$, and pta negatively affected the enzyme level of lactose metabolism, which caused the slow lactose utilization rate. The lactose permease activity of KG1, $\Delta a d h E, \Delta l d h A$ and $\Delta p t a$ was $8.07 \mathrm{nmol} / \mathrm{minute} / \mathrm{g}, 4.91 \mathrm{nmol} / \mathrm{minute} / \mathrm{g}$, $4.02 \mathrm{nmol} / \mathrm{minute} / \mathrm{g}$, and $3.98 \mathrm{nmol} /$ minute/g, respectivity. The $\beta$-galactosidase activity of KG1, $\Delta a d h E, \Delta l d h A$ and $\Delta p t a$ was $0.45 \mathrm{IU} / \mathrm{mg}, 0.28 \mathrm{IU} / \mathrm{mg}, 0.36 \mathrm{IU} / \mathrm{mg}$ and $0.27 \mathrm{IU} / \mathrm{mg}$, respectively. The low activity of lactose permease and $\beta$-galactosidase maybe the reason for inefficient lactose consumption. However, the reasons for the altered lactose fermentation in mutants need further study.

\section{Conclusions}

The engineering strategy pursued in this study, which was based on the redirection of carbons toward the production of byproducts, led to the development of $K$. pneumoniae strains with high efficiency for $2,3-\mathrm{BD}$ production. In conclusion, 2,3-BD production was dramatically improved with knockout of $a d h E$ and $p t a$. Knockout of $l d h A$ could advance faster cell growth and shorter fermentation time. The double-mutant strain with deletion of adhE and $l d h A$ resulted in accelerated fermentation and higher 2,3-BD production, although the best fermentation results in our engineered strain are almost at the same level as in wildtype microorganisms. However, we expanded the source strain for 2,3-BD fermentation and decreased the fermentation time, but we think that even genetic engineering is more efficient than traditional screening for 2,3-BD fermentation. In the near future, we should focus on optimizing the fermentation and purification to obtain a high $2,3-\mathrm{BD}$ yield. In summary, these results provide new insights for industrial production of 2,3-BD.

\section{Materials and methods}

Plasmids, strains, and construction of plasmids

K. pneumoniae KG1, which was deposited at the China Center of Industries Culture Collection (CICC 10781), 
Table 4 Strains and plasmids used in this work

\begin{tabular}{|c|c|c|}
\hline Strain, plasmid & Genotype, properties & Source or reference \\
\hline \multicolumn{3}{|l|}{ Strains } \\
\hline \multicolumn{3}{|l|}{ K. pneumoniae } \\
\hline KG1 & parent strain (KG1) & [19] \\
\hline$\Delta / d h A$ & A lactate-deficient mutant of KG1 & This work \\
\hline$\Delta a d h E$ & An alcohol dehydrogenase-deficient mutant of KG1 & This work \\
\hline$\Delta p t a$ & An phosphate acetyltransferase gene-deficient mutant of KG1 & This work \\
\hline$\Delta / d h A \Delta a d h E$ & A lactate and alcohol dehydrogenase, both deficient mutants of KG1 & This work \\
\hline \multicolumn{3}{|l|}{ E. coli } \\
\hline $\mathrm{DH} 5 \mathrm{a}$ & \$80 lacZ $\Delta$ M15 $\Delta$ lacU169 recA1 endA1 hsdR17 supE44 thi-1 gyrA relA1 & TaKaRa \\
\hline S17-1 גpir & TpR SmR recA thi-1 pro hsdR-M+RP4: 2-Tc:Mu: Km Tn7 גpir & [31] \\
\hline \multicolumn{3}{|l|}{ Plasmids } \\
\hline pRE112 & Suicide vector $\mathrm{Cm}^{\mathrm{R}}$ SacB oriT oriv & [31] \\
\hline $\mathrm{p}-/ d h \mathrm{~A}^{\prime}$ & $\mathrm{Cm}^{\mathrm{R}}$, pRE112 derivative, where a 625-bp DNA fragment containing the IdhA' was inserted & This work \\
\hline $\mathrm{p}$-adh $\mathrm{E}^{\prime}$ & $\mathrm{Cm}^{\mathrm{R}}$, pRE112 derivative, where a 872-bp DNA fragment containing the adhE' was inserted & This work \\
\hline p-pta & $\mathrm{Cm}^{\mathrm{R}}$, pRE112 derivative, where a 901-bp DNA fragment containing the pta' was inserted & This work \\
\hline
\end{tabular}

was used for the parent strain for 2,3-BD production [19]. The plasmids and strains used in this study are listed in Table 4. The Escherichia coli strain DH5 $\alpha$ was used for the construction and amplification of plasmids. Total genomic DNA of K. pneumoniae and E. coli cells were extracted using the AxyPrep Bacterial Genomic DNA Miniprep kit. The primers used in this study are listed in Table 5.

The ldhA' fragment (an 805 bp segment of truncated ldhA gene) (GeneID: 5339517 [Genbank]) was amplified by PCR using total genomic DNA as a template and primers $l d h \mathrm{~A}^{\prime}$-up and $l d h$ 'A-down, which were designed using the sequence information of $l d h A$ of K. pneumoniae. The PCR mixture consisted of $1 \mathrm{ng}$ of genomic DNA, $0.2 \mathrm{mmol}$ each dNTP, $0.2 \mu \mathrm{mol}$ each primer, $2 \mu \mathrm{L}$ of rTaq PCR buffer, and 1 unit of rTaq DNA polymerase (TaKaRa, Dalian, China) in a total volume of $20 \mu \mathrm{L}$. The

Table 5 Primers used in this work

\begin{tabular}{cr}
\hline Primer name & Primer sequences \\
\hline IdhA'-up & 5'-CGGGGTACCACGGTTGCGAACGGTATGTA-3'(Kpn I) \\
IdhA'-down & 5'-CGAGCTCAGTGGTCTCCGAAATGCTGA-3'(Sac I) \\
adhE'-up & 5'-CATGCATGCACCATCGTACGTAA AGGTGC-3'(Sph I) \\
adhE'-down & 5'-CGAGCTCTTCGGAATACCCAGCTCAGC-3'(Sac I) \\
pta' -up & 5'-CATGCATGCCAACTACATCAACGCCGACTGG-3'(Sphl) \\
pta'-down & 5'-CGAGCTCCGCTTTGTACGTGGTGTTACCG-3'(Sacl) \\
cat-up & 5'-CGGGCCCTAAATACCTGTGACGGAAGAT-3' \\
cat-down & 5'-ATCGGGCCCTATCACTTATTCAGGCGTAGC-3' \\
A-down & 5'-TACAAAACCAGCACCGTCCCT-3' \\
P-down & 5'-CGCTGTGGATGACCCGCAACG-3' \\
L-down & 5'-CCGTCCGACACTTACCTTCC-3' \\
\hline
\end{tabular}

PCR reaction was carried out at $95^{\circ} \mathrm{C}$ for 5 minutes, followed by 30 cycles at $95^{\circ} \mathrm{C}$ for $40 \mathrm{~s}, 63^{\circ} \mathrm{C}$ for $90 \mathrm{~s}, 72^{\circ} \mathrm{C}$ for $120 \mathrm{~s}$, and a final extension step of $72^{\circ} \mathrm{C}$ for $10 \mathrm{mi}$ nutes. The $a d h E^{\prime}$ (an 872-bp segment of truncated $a d h E$ (GeneID: 5341804 [Genbank]) gene) and pta' (an 901-bp segment of truncated pta (GeneID: 5338823 [Genbank]) gene) fragments were amplified by PCR using the corresponding primers. The PCR reaction procedure was the same as that of $l d h A$, but the annealing temperatures were $52^{\circ} \mathrm{C}$ and $57^{\circ} \mathrm{C}$, respectively.

The ldhA' fragment was cloned into the pRE112 [31] suicide vector after digestion with $K p n$ I and $S a c$ I, and then $180 \mathrm{bp}$ was digested by Sph I, which resulted in vector $\mathrm{p}$-ldhA'. The strain containing the $\mathrm{p}$-ldhA' plasmid was used as a donor in conjugation with KG1. Transconjugants were selected for both chloromycetin resistance from pRE112 insertion and ampicillin resistance because the KG1 strain was resistant to ampicillin, whereas E. coli S17-1 was sensitive. To construct padhE', the DNA fragment of $a d h E^{\prime}$ was cleaved by Sph I and $S a c$ I, and then ligated into the Sph I and Sac I sites of pRE112. The p-pta' plasmid was constructed by cloning the $p t a$ ' DNA fragment into the vector pRE112 using the restrictions sites SphI and SacI.

\section{Construction of the gene-deficient mutants}

To construct the gene-deficient mutants, E. coli S17-1, containing the plasmids p-ldhA, p-adhE, and p-pta, was used as a donor in conjugation with KG1. Transconjugants were selected by Luria-Bertani (LB) plates with $100 \mu \mathrm{g} / \mathrm{mL}$ ampicillin and $30 \mu \mathrm{g} / \mathrm{mL}$ chloromycetin. PCR was used to confirm that the transconjugants were the correct insertion mutants. Oligonucleotides primer cat-up and primer cat-down were 
designed to amplify a 940-bp segment of p-ldhA. Total DNA from KG1 and the four transconjugants were used as a template, and the $\mathrm{p}$-ldhA plasmid DNA was used as a positive contrast. Primer cat-up and primer L-down were used to verify the gene deletion of fixed-point validation. The $l d h A$ mutant strains were verified by PCR using the primers cat-up and L-down, with the $5^{\prime}$ region of the cat (5'-CGGGCCCTAAATACCTGTGACGGAAGAT-3') and the $3^{\prime}$ region of the chromosome of $K$. pneumoniae (5'CCGTCCGACACTTTACCTTCC-3'). The adhE mutant strains were also verified by PCR using primers cat-up and A-down, whereas the pta mutant strains were verified by PCR using primers cat-up and P-down.

To make the $\triangle a d h E \Delta l d h A$ double mutant, the $\Delta l d h A$ was cultured on $10 \%$ sucrose plates to select doublecrossover transconjugants. Proper in-frame deletion of the $l d h A$ gene was verified by PCR. And E. coli S17-1, containing the plasmids $\mathrm{p}$-adhE' as described above was used as a donor in conjugation with $K$. pneumoniae $\Delta l d h A$. Correct integration of the $a d h E$ deletion was confirmed by PCR using primers as described above.

\section{Media and cultivation conditions}

The E. coli strain DH5 $\alpha$ was incubated in LB medium with $30 \mu \mathrm{g} / \mathrm{mL}$ kanamycin or $25 \mu \mathrm{g} / \mathrm{mL}$ chloramphenicol resistances for plasmid maintenance. The glucose fermentation medium ( $\mathrm{pH}$ 7.0) was composed of glucose $(80 \mathrm{~g} / \mathrm{L})$, yeast extract $(10 \mathrm{~g} / \mathrm{L}), \mathrm{KH}_{2} \mathrm{PO}_{4}(10 \mathrm{~g} / \mathrm{L})$, $\mathrm{K}_{2} \mathrm{HPO}_{4}(7.2 \mathrm{~g} / \mathrm{L}),\left(\mathrm{NH}_{4}\right)_{2} \mathrm{SO}_{4}(2 \mathrm{~g} / \mathrm{L})$, sodium citrate $(4 \mathrm{~g} / \mathrm{L})$, and trace element solution $(1 \mathrm{~mL})$. K. pneumoniae was cultured in the glucose fermentation medium at $35^{\circ} \mathrm{C}$ and $150 \mathrm{rpm}$.

The trace element solution was composed of the following: $3 \mathrm{~g} / \mathrm{L}$ ethylenediaminetetraacetic acid (EDTA); $0.09 \mathrm{~g} / \mathrm{L} \mathrm{CaCl}{ }_{2} \cdot 2 \mathrm{H}_{2} \mathrm{O} ; 0.90 \mathrm{~g} / \mathrm{L} \mathrm{ZnSO}_{4} \cdot 7 \mathrm{H}_{2} \mathrm{O} ; 0.60 \mathrm{~g} / \mathrm{L}$ $\mathrm{FeSO}_{4} \cdot 7 \mathrm{H}_{2} \mathrm{O} ; 200 \mathrm{mg} / \mathrm{L} \mathrm{H}_{3} \mathrm{BO}_{3} ; 156 \mathrm{mg} / \mathrm{L} \mathrm{MgCl}_{2}$. $2 \mathrm{H}_{2} \mathrm{O} ; 80 \mathrm{mg} / \mathrm{L} \mathrm{Na}_{2} \mathrm{MoO}_{4} \cdot 2 \mathrm{H}_{2} \mathrm{O} ; 60 \mathrm{mg} / \mathrm{L} \mathrm{CoCl}_{2}$. $2 \mathrm{H}_{2} \mathrm{O} ; 60 \mathrm{mg} / \mathrm{L} \mathrm{CuSO}_{4} \cdot 5 \mathrm{H}_{2} \mathrm{O}$; and $20 \mathrm{mg} / \mathrm{L} \mathrm{KI}$. The $\mathrm{pH}$ of the trace element solution was adjusted to 4.00 with $\mathrm{NaOH}$, and then the solution was autoclaved.

Seed culture $(10 \%, \mathrm{v} / \mathrm{v})$ was inoculated into the fermentation medium and batch and fed-batch fermentation was carried out in a 5 - $\mathrm{L}$ stirring bioreactor (Biostat A plus, B Braun, Melsungen, Germany) with a working volume of $3 \mathrm{~L}$. The fermentation was performed at $37^{\circ} \mathrm{C}$ with the aeration rate of 1.0 volume per volume per minute (vvm) and agitation speed was automatically changed to maintain $15 \%$ dissolved oxygen (DO) level, respectively. When the $\mathrm{pH}$ decreased to 6.5 , it was controlled at 6.5 automatically by adding $3 \mathrm{M} \mathrm{NaOH}$.

\section{Analytical methods}

The protein concentration in the extracts was measured according to the Bradford method using the Bio-Rad protein reagent and ovalbumin as the standard [32]. Biomass was determined using a UV-visible spectroscopy system (8453, Agilent, Palo Alto, CA., USA) at $600 \mathrm{~nm}$ with appropriate dilution, and was converted to the dry cell weight (DCW). The intracellular NADH and $\mathrm{NAD}^{+}$concentrations were measured by procedures presented by Ji et al. [17]. The concentrations of glucose, 2,3-BD, acetic acid, lactic acid, acetoin, alcohol, and acetoin were determined by high-performance liquid chromatography using an Aminex HPX-87H column at $65^{\circ} \mathrm{C}$, with $5 \mathrm{mM} \mathrm{H}_{2} \mathrm{SO}_{4}$ as the mobile phase at a flow rate of $0.6 \mathrm{~mL} / \mathrm{minute}$.

\section{Enzyme activity measurements}

ADH activity was determined according to the method described by Cunningham et al. [33]. To determine the enzyme activity, cells were harvested after $18 \mathrm{~h}$ of culture under anaerobic conditions, washed with MOPS buffer (50 mM, pH 7.4, containing $4 \mathrm{mM} \mathrm{DTT,} 10 \mathrm{mM} \mathrm{MgSO}_{4}$, and $10 \mu \mathrm{M} \mathrm{MnSO}_{4}$ ), and resuspended with MOPS buffer up to $2.5 \mathrm{~mL}$. The cells were then processed by ultrasonication to collect the crude extracts. The $\mathrm{ADH}$ reaction mixtures contained the following in a total volume of $1 \mathrm{~mL}$ : $75 \mathrm{nmol} \mathrm{NAD}{ }^{+}, 100 \mathrm{nmol} \mathrm{CoA}, 10 \mu \mathrm{L}$ of $1.0 \mathrm{M}$ acetaldehyde, $20 \mu \mathrm{L}$ of crude extracts, and CHES buffer $(12 \mathrm{mM}$, $\mathrm{pH}$ 8.5). The ADH reaction mixture contained the following in a total volume of $1 \mathrm{~mL}: 75 \mathrm{nmol} \mathrm{NAD}{ }^{+}, 20 \mu \mathrm{L}$ of alcohol, $20 \mu \mathrm{L}$ of crude extracts, and sodium pyrophosphate solution (12 mM, pH 8.5). One unit of enzyme activity was defined as the generation of $1 \mu \mathrm{mol} \mathrm{NADH}$ per minute.

The LDH activity was determined according to the method established by Tarmy et al. [34]. The enzyme reaction mixtures contained the following in a total volume of $1 \mathrm{~mL}$ : $0.33 \mathrm{mM} \mathrm{NADH}, 30 \mathrm{mM}$ sodium pyruvate, $20 \mu \mathrm{L}$ of crude extracts, and potassium phosphate buffer. The cells were harvested after $12 \mathrm{~h}$ of culture under aerobic conditions. The crude extracts were extracted using the same method previously mentioned, except for the addition of potassium phosphate buffer instead of MOPS buffer. The unit of enzyme activity was defined as the oxidation of $1 \mu \mathrm{mol} \mathrm{NADH}$ per minute.

The PTA activity was determined according to previous studies, with minor modifications [35]. The enzyme reaction mixture contained the following in a total volume of $3.005 \mathrm{~mL}$ : $2.95 \mathrm{~mL}$ of $0.1 \mathrm{M}$ potassium phosphate buffer $(\mathrm{pH} 7.4), 20 \mu \mathrm{L}$ of $0.2 \mathrm{mM}$ acetyl-CoA, $30 \mu \mathrm{L}$ of $0.08 \mathrm{mM}$ DTNB, and $5 \mu \mathrm{L}$ of dialyzed extract. The cells were harvested after $18 \mathrm{~h}$ of culture under aerobic conditions. The crude extracts were extracted using the same method previously mentioned, except for the addition of potassium phosphate buffer instead of MOPS buffer. One unit of PTA was defined as the amount of enzyme that generates $1 \mathrm{nmol}$ CoA per minute.

The activity of $\beta$-galactosidase was determined by our previous reported [36]. The lactose permease activity 
was determined as the method of maltose permease activities [37], with minor modifications (lactose was used as the maltose). One unit of lactose permease was defined as the amount of lactose uptake by $1 \mathrm{~g}$ DCW biomass per minute.

The method for calculating the $\mathrm{NADH}_{2}$ balance and carbon recovery was as previously reported [38]. The biochemical reactions involved in the metabolism of glucose by K. pneumoniae under microaerobic conditions can be written as follows $[4,29,38]$ :

$$
\begin{aligned}
& \text { Glucose } \rightarrow \text { 2acetic acid }+2 \mathrm{NADH}+4 \mathrm{ATP}+2 \mathrm{CO}_{2}+ \\
& 2 \text { fomate }-2 \mathrm{H}_{2} \mathrm{O} \\
& \text { Glucose } \rightarrow \text { 2ethanol }+2 \mathrm{ATP}+2 \mathrm{CO}_{2}+2 \text { formate }+ \\
& 2 \mathrm{H}_{2} \mathrm{O}-2 \mathrm{NADH} \\
& \text { Glucose } \rightarrow 2,3-\mathrm{BD}+2 \mathrm{ATP}+2 \mathrm{CO}_{2}+\mathrm{NADH}+2 \mathrm{H}_{2} \mathrm{O} \\
& \text { Glucose } \rightarrow \text { Aceion }+2 \mathrm{ATP}+2 \mathrm{CO}_{2}+2 \mathrm{NADH}+2 \mathrm{H}_{2} \mathrm{O} \\
& \text { Glucose } \rightarrow \text { 2lactic acid }+2 \mathrm{ATP}+2 \mathrm{H}_{2} \mathrm{O} \\
& \text { Glucose } \rightarrow \text { 2succinic acid }+2 \mathrm{ATP}+2 \mathrm{H}_{2} \mathrm{O}-2 \mathrm{NADH}
\end{aligned}
$$

The NADH2 balance and carbon recovery can be calculated as follows:

$$
\begin{gathered}
\mathrm{R}_{\mathrm{H}}=\left(2 \mathrm{q}_{\mathrm{EtOH}}+2 \mathrm{q}_{\mathrm{SUC}}\right) /\left(2 \mathrm{q}_{\mathrm{HAC}}+\mathrm{q}_{\mathrm{BD}}+2 \mathrm{q}_{\mathrm{ACE}}\right. \\
+13.2 \mu) \\
\mathrm{R}_{\mathrm{C}}=\left(2 \mathrm{q}_{\mathrm{EtOH}}+2 \mathrm{q}_{\mathrm{SUC}}+2 \mathrm{q}_{\mathrm{HAC}}+\mathrm{q}_{\mathrm{BD}}+2 \mathrm{q}_{\mathrm{ACE}}\right. \\
\left.+13.2 \mu+2 \mathrm{q}_{\mathrm{Lac}}\right) / \mathrm{q}_{\mathrm{s}}
\end{gathered}
$$

Where $\mathrm{q}_{\mathrm{ACE}}=$ specific formation rate of aceion $\mathrm{mmol} / \mathrm{g} / \mathrm{h}$; $\mathrm{q}_{\mathrm{BD}}=$ specific formation rate of 2,3-butanediol $\mathrm{mmol} / \mathrm{g} / \mathrm{h}$; $\mathrm{q}_{\mathrm{EtOH}}=$ specific formation rate of ethanol $\mathrm{mmol} / \mathrm{g} / \mathrm{h} ; \mathrm{q}_{\mathrm{HAc}}=$ specific formation rate of acetic acid $\mathrm{mmol} / \mathrm{g} / \mathrm{h} ; \mathrm{q}_{\mathrm{Lac}}=\mathrm{spe}-$ cific formation rate of lactic acid $\mathrm{mmol} / \mathrm{g} / \mathrm{h} ; \mathrm{q}_{\mathrm{S}}=\mathrm{specific}$ consumption rate of glucose $\mathrm{mmol} / \mathrm{g} / \mathrm{h} ; \mathrm{q}_{\mathrm{SuC}}=$ specific formation rate of succinic acid $\mathrm{mmol} / \mathrm{g} / \mathrm{h} ; \mathrm{R}_{\mathrm{C}}=$ carbon $\mathrm{recov}-$ ery; $R_{H}=$ reducing equivalents recovery; $\mu=$ specific growth rate/h.

\section{Abbreviations \\ 2,3-BD: 2,3-Butanediol; ADH: acetaldehyde dehydrogenase; bp: base pairs; DCW: dry cell weight; DO: dissolved oxygen; KG1: K. pneumonia parent strain; LB: Luria-Bertani; LDH: lactate dehydrogenase; NAD+: nicotinamide adenine dinucleotide; NADH: nicotinamide adenine dinucleotide plus hydrogen;

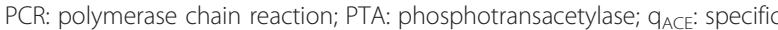 formation rate of aceion $\mathrm{mmol} / \mathrm{g} / \mathrm{h}$; $\mathrm{q}_{\mathrm{BD}}$ : specific formation rate of 2,3-butanediol $\mathrm{mmol} / \mathrm{g} / \mathrm{h}$; $\mathrm{q}_{\mathrm{E} \text { Нн: }}$ specific formation rate of ethanol $\mathrm{mmol} / \mathrm{g} / \mathrm{h}$; $\mathrm{q}_{\mathrm{HAc}}$ : specific formation rate of acetic acid $\mathrm{mmol} / \mathrm{g} / \mathrm{h}$; q ac: specific formation rate of lactic acid $\mathrm{mmol} / \mathrm{g} / \mathrm{h}$; qs: specific consumption rate of glucose $\mathrm{mmol} / \mathrm{g} / \mathrm{h}$; qsuc: specific formation rate of succinic acid mmol/g/h; $R_{c}$ : carbon recovery; $R_{H}$ : reducing equivalents recovery; $\mu$ : specific growth rate/h.}

\section{Competing interests}

The authors declare that they have no competing interests.

\section{Authors' contributions}

$X G$ designed and performed the experiments, and drafted the manuscript; CC, YW, CL and MW performed some experiments, analyzed data and drafted the manuscript; $C Z$ and $Y C$ provided some reagents, helped to design the experiment and drafted the manuscript; HP and DX designed the experiments and supervised the project; XG, HP and DX analyzed the data and critically revised the manuscript. All of the authors read and approved the manuscript.

\section{Acknowledgements}

This research was financed by the Cheung Kong Scholars and Innovative Research Team Program in University of Ministry of Education, China (Grant Number IRT1166), the National High Technology Research, and the Development Program of China (863 Program) (Grant Number 2012AA022108), the National Agricultural Research Projects Funded (Grant Number 2012AA101805). The authors thank Dr Haixia Xie (Institute of Hydrobiology, Chinese Academy of Sciences, China) for providing the

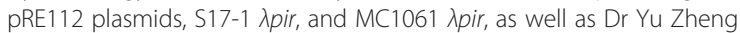
(Tianjin University of Science and Technology, China) for providing the K. pneumoniae KG1 strain.

Received: 19 November 2013 Accepted: 13 March 2014

Published: 26 March 2014

\section{References}

1. van Haveren J, Scott EL, Sanders J: Bulk chemicals from biomass. Biofuels Bioprod Bioref 2007, 2:41-57.

2. Ragauskas AJ, Williams CK, Davison BH, Britovsek G, Cairney J, Eckert CA, Frederick WJ Jr, Hallett JP, Leak DJ, Liotta CL, Mielenz JR, Murphy R, Templer $\mathrm{R}$, Tschaplinski T: The path forward for biofuels and biomaterials. Science 2006, 311:484-498.

3. Celińska E, Grajek W: Biotechnological production of 2,3-butanediol-current state and prospects. Biotechnol Adv 2009, 27:715-725.

4. Ji XJ, Huang H, Ouyang PK: Microbial 2, 3-butanediol production: a state of-the-art review. Biotechnol Adv 2011, 29:351-364.

5. Syu MJ: Biological production of 2, 3-butanediol. Appl Microbiol Biotechnol 2001, 55:10-18.

6. Garg SK, Jain A: Fermentative production of 2, 3-butanediol: a review. Bioresour Technol 1995, 51:103-109.

7. Ma CQ, Wang AL, Qin JY, Li LX, Ai XL, Jiang TY, Tang HZ, Xu P: Enhanced 2,3-butanediol production by Klebsiella pneumoniae SDM. Appl Microbiol Biotechnol 2009, 82:49-57.

8. Petrov K, Petrova P: High production of 2, 3-butanediol from glycerol by Klebsiella pneumoniae G31. Appl Microbiol Biotechnol 2009, 84:659-665.

9. Jung MY, Ng CY, Song H, Lee J, Oh MK: Deletion of lactate dehydrogenase in Enterobacter aerogenes to enhance 2, 3-butanediol production. Appl Microbiol Biotechnol 2012, 95:461-469.

10. Wang Q, Chen T, Zhao X, Chamu J: Metabolic engineering of thermophilic bacillus licheniformis for chiral pure D-2,3-butanediol production. Biotechnol Bioeng 2012, 109:1610-1621.

11. Ji XJ, Huang H, Zhu JG, Ren LJ, Nie ZK, Du J, Li S: Engineering Klebsiella oxytoca for efficient 2, 3-butanediol production through insertional inactivation of acetaldehyde dehydrogenase gene. Appl Microbiol Biotechnol 2010, 85:1751-1758.

12. Zeng AP, Biebl H, Deckwer WD: Effect of $\mathrm{pH}$ and acetic acid on growth and 2,3-butanediol production of Enterobacter aerogenes in continuous culture. Appl Microbiol Biotechnol 1990, 33:485-489.

13. Zeng AP, Deckwer WD: A model for multiproduct-inhibited growth of Enterobacter aerooenes in 2,3-butanediol fermentation. Appl Microbiol Biotechnol 1991, 35:1-3.

14. Zeng AP, Ross A, Biebl H, Tag C, Günzel B, Deckwer WD: Multiple product inhibition and growth modeling of Clostridium butyricum and Klebsiella pneumoniae in glycerol fermentation. Biotechnol Bioeng 1994, 44:902-911.

15. Gaspar P, Neves AR, Gasson MJ, Shearman CA, Santos H: High yields of 2,3-butanediol and mannitol in Lactococcus lactis through engineering of NAD + cofactor recycling. Appl Environ Microbiol 2011, 77:6826-6835.

16. Zhu JB, Long MN, Xu FC, Wu XB, Xu HJ: Enhanced hydrogen production by insertional inactivation of $a d h E$ gene in Klebsiella oxytoca HP1. Chin Sci Bull 2007, 52:492-496.

17. Ji XJ, Xia ZF, Fu NH, Nie ZK, Shen MQ, Tian QQ, Huang H: Cofactor engineering through heterologous expression of an NADH oxidase and its impact on metabolic flux redistribution in Klebsiella pneumoniae. Biotechnol Biofuels 2013, 6:7

18. Zhang YP, Li Y, Du CY, Liu M, Cao ZA: Inactivation of aldehyde dehydrogenase: a key factor for engineering 1, 3-propanediol production by Klebsiella pneumoniae. Metab Eng 2006, 8:578-586. 
19. Zheng $Y$, Zhang HY, Zhao L, Wei LJ, Ma XY, Wei DZ: One-step production of 2, 3-butanediol from starch by secretory over-expression of amylase in Klebsiella pneumoniae. J Chem Technol Biotechnol 2008, 83:1409-1412.

20. Fond O, Jansen NB, Tsao GT: A model of acetic acid and 2, 3-butanediol inhibition of the growth and metabolism of Klebsiella oxytoca. Biotechnol Lett 1985, 7:727-732.

21. Kosaric N, Magee RJ, Blaszczyk R: Redox potential measurement for monitoring glucose and xylose conversion by K. pneumoniae. Chem Biochem Eng Q 1992, 6:145-152.

22. Booth IR: Regulation of cytoplasmic pH in bacteria. Microbiol Rev 1985, 49:359-378.

23. Jang YS, Park JM, Choi S, Choi YJ, Seung DY, Cho JH, Lee SY: Engineering of microorganisms for the production of biofuels and perspectives based on systems metabolic engineering approaches. Biotechnol Adv 2011, 30:989-1000

24. Berríos-Rivera SJ, Bennett GN, San KY: Metabolic engineering of Escherichia coli: increase of NADH availability by overexpressing an NAD + -dependent formate dehydrogenase. Metab Eng 2002, 4:217-229.

25. Seo MY, Seo JW, Heo SY, Baek JO, Rairakhwada D, Oh BR, Seo PS, Choi MH, Kim CH: Elimination of by-products formation during production of 1, 3-propanediol in Klebsiella pneumoniae by inactivation of glycerol oxidative pathway. Appl Microbiol Biotechnol 2009, 84:527-534.

26. Kleiner D, Paul W, Merrick MJ: Construction of multicopy expreesion vectors for regulated overproduction of proteins in Klebsiella pneumoniae and other enteric bacteria. J Gen Microbio/ 1988, 134:1779-1784.

27. Yang G, Tian JS, Li JL: Fermentation of 1, 3-propanediol by a lactate deficient mutant of Klebsiella oxytoca under microaerobic conditions. Appl Microbiol Biotechnol 2007, 73:1017-1024.

28. Kim DK, Rathnasingh C, Song H, Lee HJ, Seung D, Chang YK: Metabolic engineering of a novel Klebsiella oxytoca strain for enhanced 2,3-butanediol production. J Biosci Bioeng 2013, 116:186-192.

29. Zhang L, Yang $Y$, Sun J, Shen $Y$, Wei D, Zhu J, Chu J: Microbial production of 2,3-butanediol by a mutagenized strain of Serratia marcescens $\mathrm{H} 30$. Bioresour Technol 2010, 101:1961-1967.

30. Lee HK, Maddox IS: Microbial production of 2, 3-butanediol from whey permeate. Biotechnol Lett 1984, 6:815-818.

31. Edwards RA, Keller LH, Schifferli DM: Improved allelic exchange vectors and their use to analyze 987P fimbria gene expression. Gene 1998, 207:149-157.

32. Bradford MM: A rapid and sensitive method for the quantitation of microgram quantities of protein utilizing the principle of protein-dye binding. Anal Biochem 1976, 72:248-254.

33. Cunningham PR, Clark PD: The use of suicide substrates to select mutants of Escherichia coli lacking enzymes of alcohol fermentation. Mol Gen Genet 1986, 205:487-493.

34. Tarmy EM, KaPlan NO: Chemieal characterization of D-lactate dehydrogenase from Escheriehia coli B. J Biol Chem 1968, 271:2579-2586.

35. Andersch W, Bahl H, Gottschalk $\mathrm{G}$ : Level of enzymes involved in acetate, butyrate, acetone and butanol formation by Clostridium acetobutylicum. Eur J Appl Microbiol Biotechnol 1983, 18:327-332.

36. Zou J, Guo X, Shen T, Dong J, Zhang C, Xiao D: Construction of lactose-consuming Saccharomyces cerevisiae for lactose fermentation into ethanol fue. J Ind Microbiol Biotechnol 2013, 40:353-363.

37. Houghton-Larsen J, Brandt A: Fermentation of high concentrations of maltose by Saccharomyces cerevisiae is limited by the COMPASS methylation complex. Appl Environ Microbiol 2006, 72:7176-7182.

38. Zeng AP, Biebl H, Deckwer WD: Pathway analysis of glycerol fermentation by Klebsiella pneumoniae: regulation of reducing equivalent balance and product formation. Enzyme Microb Technol 1993, 15:770-779.

doi:10.1186/1754-6834-7-44

Cite this article as: Guo et al:: Effect of the inactivation of lactate dehydrogenase, ethanol dehydrogenase, and phosphotransacetylase on 2,3-butanediol production in Klebsiella pneumoniae strain. Biotechnology for Biofuels 2014 7:44.

\section{Submit your next manuscript to BioMed Central and take full advantage of:}

- Convenient online submission

- Thorough peer review

- No space constraints or color figure charges

- Immediate publication on acceptance

- Inclusion in PubMed, CAS, Scopus and Google Scholar

- Research which is freely available for redistribution

Submit your manuscript at www.biomedcentral.com/submit
C) Biomed Central 